\title{
ATTITUDE TOWARDS PERSONAL PROTECTIVE EQUIPMENT IN THE FRENCH NUCLEAR FUEL INDUSTRY
}

\author{
Irina GUSEVA CANU ${ }^{1,2}$, Ségolène FAUST ${ }^{1,3}$, Pierre CANIONI ${ }^{4}$, Philippe COLLOMB ${ }^{5}$, \\ Eric SAMSON ${ }^{1}$, and Dominique LAURIER ${ }^{1}$ \\ IRSN/PRP-Homme/SRBE/LEPID, Fontenay-aux-Roses ${ }^{1}$, In VS/ DST, Saint Maurice ${ }^{2}$, DIRECCTE \\ Champagne-Ardenne, Châlons-en-Champagne ${ }^{3}$ EURODIF-production ${ }^{4}$, AREVA $^{5}$, Service Santé du Travail,
} Pierrelatte, France

Received in July 2012

CrossChecked in April 2013

Accepted in December 2012

\begin{abstract}
This descriptive cross-sectional study examines the compliance of workers from the European Gaseous Diffusion Uranium Enrichment Consortium (EURODIF) with personal protection equipment (PPE) in view of the various hazards in the nuclear fuel industry. The PPE inventory was drawn up by an industrial hygienist in charge of the PPE at EURODIF. Two hundred and twenty seven (10\%) randomly selected, active and retired, EURODIF workers filled in a questionnaire on their attitudes towards PPE. Exposure data from the EURODIF job exposure matrix were used to examine whether PPE usage varies according to exposure level. The study suggests a PPE usage profile that varies depending on the hazards present and PPE available. Anti-uranium PPE and gloves were among the best rated, while anti-spray goggles were the least used. We found that, for most hazards known to cause cancer or irreversible health damage, PPE usage varied according to exposure (homogeneity test, $p<0.05$; trend test, $p<0.05$ ). The continuous use of PPE among workers should be encouraged through improvements to the PPE management system. A precise model of individual exposure can only be designed if the use and efficiency of PPE are taken into consideration.
\end{abstract}

KEY WORDS: epidemiology, nuclear workers, uranium

In order to study the health effects of internal irradiation from inhaling uraniferous compounds, an exposure assessment survey was conducted in several French nuclear industry plants (1). Specific job exposure matrices (JEMs) covering the different hazards present in the industry [uraniferous compounds, potentially carcinogenic, mutagen or reprotoxic chemicals (CMR) (2), noise, metal dusts, electromagnetic fields, and heat] were built for the AREVA-NC Pierrelatte (3) and European Gaseous Diffusion Uranium Enrichment (EURODIF) (4) companies. These JEMs enabled the calculation of individual cumulative exposure scores for each hazard.
However, to correctly model the internal exposure dose, we took into account the personal protection equipment (PPE) use and efficiency. This study was aimed at describing the attitudes of workers in the nuclear fuel industry towards PPE for further epidemiological investigation.

\section{MATERIALS AND METHODS}

The study was conducted at EURODIF, which produces uranium hexafluoride enriched to $3 \%$ to $5 \%$ in ${ }^{235} \mathrm{U}$, between July and October 2010. Apart from 
the four gaseous diffusion plants, EURODIF includes a uranium treatment annex, auxiliary fluid utilities, the Reception-Shipping-Control Department, repair workshops, and a physical-chemical analysis laboratory.

This descriptive study used a cross-sectional design to examine the workers' compliance with PPE in view of various hazards present in the nuclear fuel industry. It was based on an inventory of currently available PPE, the assessment of its adequacy and availability, and a self-administered questionnaire on its usage and reasons to neglect it despite recommendations.

\section{Inventory of provided PPE and performance}

The levels of exposure to different hazards were assessed retrospectively for the period between 1978 and 2010, based on a EURODIF-specific JEM (4). In this JEM, exposure was assessed without taking into account PPE described in previous studies $(3,5,6)$. In order to account for the effect of PPE on the workers' individual exposure, an inventory of the currently used PPE and associated collective protection measures was performed for different hazards by an industrial hygienist at EURODIF. Archived documents were inspected to complete the inventory with previously used PPE. The adequacy and performance of the available PPE were assessed by considering the compliance with PPE management system procedures for all categories of hazards. These procedures were retrieved from the EURODIF occupational safety and occupational medicine departments. Temporal changes in the PPE management system application were identified during interviews with the industrial hygienist.

\section{Questionnaire}

The inventory helped create the questionnaire on the workers' attitudes regarding PPE at each workstation and listed the existing PPE for each type of hazard by their generic names: goggles, overalls or work clothes, gloves, breathing protection, earplugs, and earmuffs. Beside each PPE were checkboxes for answers to the following three questions: (1) Was the PPE available? (yes/no); (2) Was the PPE used when its use was recommended? [Never/Occasionally (in the event of an incident or inspection)/Systematically]; (3) Why was PPE not used when recommended? (Did not feel the need/ A hindrance or uncomfortable/ Misplaced or disappeared).

\section{The survey}

The questionnaire was distributed to workers who represented the 101 EURODIF workstations defined in the JEM during a previous exposure assessment survey (4). For each workstation, 5 to 10 active workers with a seniority of more than five years at the same workstation were selected randomly by automatic procedure. They were contacted via safety correspondents, and those consenting to participate $(n=300)$ received the assessment documents. After having completed the questionnaire, the evaluators used a prepaid envelope addressed to the study manager at the IRSN, remaining anonymous. Retired evaluators were contacted by mail and their contact details were obtained from the EURODIF Human Resources Department. The assessment document was sent to all non-administrative retired staff younger than 85 years of age $(n=370)$.

\section{Treatment and analysis of the collected data}

The answers were computerized and analysed at the IRSN using the Stata version 11 software. Each evaluator was asked to answer depending on his/her knowledge about the exposures, working conditions, and professional attitudes for one or more workstations. The answers were examined according to the procedure derived from the Delphi method (4) in order to yield a uniform answer for each workstation. This answer should represent the attitude of all workers assigned to a workstation.

The EURODIF PPE usage database was merged with the EURODIF JEM database according to the workstation number and title in order to input data on the amount of exposure for further analysis. The amount of exposure was categorized using a four-point scale, from 0 (no exposure) to 3 (high exposure). The PPE compliance across exposure amount categories was compared using the Pearson Chi-squared test. The null hypothesis was that the percentage of systematic uses, occasional uses, and failures to use the PPEs was the same regardless of the amount of exposure to a hazard. Furthermore, a linear trend test was performed to examine whether the percentage of systematic PPE use increases with exposure. 


\section{External validation of study findings}

Since no data was available on subjects from other nuclear plants or facilities, the reliability of the results was assessed by external expertise. An independent experienced industrial hygienist and ergonomist with a 30-year long seniority at the French Atomic Energy Commissariat (CEA) and AREVA NC nuclear plants was enrolled to examine: (1) the completeness of the PPE inventory, (2) the PPE appropriateness for effective protection against hazards, (3) the temporal changes in the PPE management system within the CEA/AREVA group, and (4) the consistency of the observed results with those at other CEA/AREVA plants.

\section{RESULTS}

Table 1 summarises the PPE and collective protection measures implemented within EURODIF for different types of hazards between 1978 and 2010.

Table 1 Personal and collective protection equipment used depending on the hazards at EURODIF (1978-2010)

\begin{tabular}{|c|c|c|c|}
\hline \multirow[t]{2}{*}{ Hazard } & \multicolumn{2}{|r|}{ Personal protection equipment } & \multirow{2}{*}{$\begin{array}{c}\begin{array}{c}\text { Associated collective } \\
\text { protection }\end{array} \\
\text { Type }\end{array}$} \\
\hline & Type & Detail & \\
\hline \multirow[t]{3}{*}{$\begin{array}{l}\text { Uraniferous } \\
\text { products }\end{array}$} & $\begin{array}{l}\text { Work } \\
\text { clothes }\end{array}$ & $\begin{array}{l}\text { Emmanuelle suit (airtight vinyl overalls), MURUROA suit } \\
\text { (Vinyl, airtight and ventilated) since 2001; } \\
\text { ULM suit (intervention suit sealed from gas and liquids) } \\
\text { since 2003. Tyveck suit (water repellent paper, } \\
\text { sealed from dust) } \\
\text { Cotton suit (coveralls, hood, boot covers) }\end{array}$ & Information/Zoning \\
\hline & $\begin{array}{l}\text { Breathing } \\
\text { protection }\end{array}$ & $\begin{array}{l}\text { Complete mask + A2B2P3 cartridge up to } 2003 \text {, then } \\
\text { A2B2E2K2 Hg P3 or A2B2P3 with air supply }\end{array}$ & Markers/alarm \\
\hline & Gloves & MAPA GANTEX 540 gloves & Ventilation \\
\hline \multirow[t]{4}{*}{$\begin{array}{l}\text { Emissions } \\
\text { from chemical } \\
\text { products }\end{array}$} & $\begin{array}{l}\text { Breathing } \\
\text { protection }\end{array}$ & $\begin{array}{l}\text { Complete mask + cartridge A2B2P3 until } 2003 \text { then } \\
\text { A2B2E2K2 Hg P3 or A3P3 or A2B2P3, air supply }\end{array}$ & Product substitution \\
\hline & Gloves & $\begin{array}{l}10 \text { references of chemical gloves (PCB, solvents, acids, } \\
\mathrm{ClF} 3 \text {, oils, etc.) }\end{array}$ & $\begin{array}{l}\text { Capture at the source } \\
\text { (cabin, hob) }\end{array}$ \\
\hline & Goggles & Eye mask & Ventilation \\
\hline & $\begin{array}{l}\text { Work } \\
\text { clothes }\end{array}$ & $\begin{array}{l}\text { Emmanuelle suit, Pierrelatte (airtight vinyl suit), } \\
\text { MURUROA suit (Vinyl, airtight and ventilated) from 2001, } \\
\text { Leather CIF3 suit, Tyveck suit (water repellent paper sealed } \\
\text { from dust), Anti-acid apron, ULM suit (intervention suit } \\
\text { sealed from gases and liquids) since } 2003\end{array}$ & Information \\
\hline Metal dust & $\begin{array}{l}\text { Breathing } \\
\text { protection }\end{array}$ & Complete mask above, or P3 half mask & Humidifiers \\
\hline \multirow{2}{*}{ Asbestos fibres } & $\begin{array}{l}\text { Breathing } \\
\text { protection }\end{array}$ & $\begin{array}{l}\text { Complete mask + cartridge A2B2P3 } \\
\text { until 2003, then A2B2E2K2 Hg P3 }\end{array}$ & Information \\
\hline & $\begin{array}{l}\text { Work } \\
\text { clothes }\end{array}$ & Tyveck suit (water repellent paper and sealed from dust) & \\
\hline \multirow[t]{2}{*}{ Noise } & Earmuff & OPTAC & $\begin{array}{l}\text { Separation/ sound } \\
\text { insulation }\end{array}$ \\
\hline & Ear plugs & EAR CLASSIC SNR=28 dB and moulded plugs & Covering \\
\hline $\begin{array}{l}\text { Hot } \\
\text { atmosphere }\end{array}$ & $\begin{array}{l}\text { Work } \\
\text { clothes }\end{array}$ & $\begin{array}{l}\text { MATISEC heavy temperature suit (airtight and } \\
\text { ventilated suit) } \\
\text { MATISEC light temperature suit ( } 2 \text { piece suit worn with } \\
\text { integrated breathing equipment) }\end{array}$ & $\begin{array}{l}\text { Air conditioned area, } \\
\text { Ventilation }\end{array}$ \\
\hline
\end{tabular}


Major changes in the PPE management system date from the late 1990s to 2003, when national and European standards regarding non-radiological exposure management began being applied. During the first decade of operation (1978 to 1987), radiation (uranium) exposure prevention was emphasized, as heritage from the CEA pilot uranium enrichment facilities. The PPE introduced and tested there was distributed to the EURODIF workforce composed of young, massively recruited individuals who were mainly without the military discipline and radiological risk awareness for which the CEA workforce was well-known. In view of the extent of industrial activity, as well as the width of the staff, it is difficult to determine the effectiveness of PPE usage trainings and supervision during that period. The second decade (1988 to 1997) was characterized by cost reductions including cutting costs on PPE. The aptness of certain pieces of PPE was sometimes deemed questionable by the safety engineers and industrial hygienist, and the potentially exposed staff sometimes refused to use them. Management of PPE was then entrusted to the activity managers. This resulted in heterogeneity of choice, quality, appropriateness, and maintenance of the PPE, before it could be reorganized according to the ISO recommendations implemented within the Quality Management System in the late 1990s.

The questionnaire on PPE usage was completed by 107 active and 127 retired workers with a participation rate of $32 \%$ and $36 \%$, respectively. For each workstation, four answers were received on average, making it possible to compare them and derive the most uniform answer. Among the three questions for each type of hazard, only question (1) on PPE availability was answered $100 \%$ of the time, with $100 \%$ affirmative answers. The completeness of the answers to questions (2) and (3) varied depending on the hazard type and PPE (Table 2), with a non-reply rate ranging between $12 \%$ and $60 \%$.

The PPE used systematically in the majority of workstations $(\geq 70 \%)$ were gloves for chemical products, overalls and breathing mask for uranium, and hear protective equipment. Uranium was the only hazard for which PPE was used at all the workstations for which its use was recommended. The anti-heat PPE and anti-spray goggles were the least used pieces of PPE. The reasons for not using PPE depended on the PPE. The anti-heat overalls, earmuffs, and chemical product gloves were considered a hindrance or uncomfortable, whereas the anti-spray goggles were mostly not used because they had been misplaced or perceived unnecessary. The results on the compliance with PPE use recommendation are presented in Table 3. For most hazards, especially those known to cause cancer or irreversible health damage (exposure to uranium, noise, asbestos, welding, trichloroethylene), when PPE usage varied according to the amount of exposure (homogeneity test, $p<0.05$ ), a positive tendency (i.e., more systematic PPE use) was observed as exposure increased. The only exception to this tendency was observed for gloves usage while handling chlorinated products (including perchloroethylene and $\mathrm{ClF}_{3}$ ), and gloves and work clothes usage while handling hydrocarbon fuels.

\section{DISCUSSION}

Although the present study is descriptive in nature, it yields data on PPE usage, reasons for incompliance

Table 2 Characteristics of the use of personal protection equipment (PPE) depending on the type of hazard

\begin{tabular}{|c|c|c|c|c|c|c|c|c|c|c|}
\hline \multirow[b]{2}{*}{ PPE use } & \multicolumn{2}{|c|}{ Noise } & \multirow{2}{*}{ 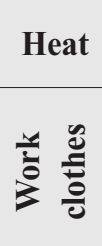 } & \multicolumn{2}{|c|}{ Uranium } & \multicolumn{4}{|c|}{ Chemical products } & \multirow{2}{*}{$\begin{array}{c}\begin{array}{c}\text { Fibres/ } \\
\text { Dust }\end{array} \\
\sum^{\frac{\gamma}{\sigma}}\end{array}$} \\
\hline & 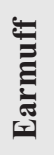 & 包 & & $\frac{\frac{N}{\tilde{E}}}{\sum^{\frac{N}{z}}}$ & $\frac{\mathscr{E}}{\ddot{\Xi}}$ & 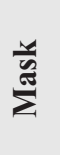 & $\frac{0}{0}$ & $\begin{array}{l}0 \\
\frac{0}{60} \\
00 \\
0 \\
0\end{array}$ & $\frac{\pi}{\bar{a}}$ & \\
\hline Never / \% & 6 & 6 & 5 & 0 & 0 & 3 & 2 & 6 & 5 & 5 \\
\hline Occasional / \% & 11 & 9 & 26 & 16 & 15 & 23 & 17 & 20 & 20 & 12 \\
\hline Systematic / \% & 71 & 65 & 34 & 68 & 70 & 51 & 72 & 41 & 50 & 24 \\
\hline Unknown / \% & 12 & 20 & 36 & 16 & 15 & 23 & 19 & 33 & 25 & 60 \\
\hline Main reason for not using* & 2 & 1 & 2 & N/A & $\mathrm{N} / \mathrm{A}$ & 1 & 2 & 1,3 & 1 & 1 \\
\hline
\end{tabular}

$* 1=$ did not feel the need; $2=$ a hindrance, uncomfortable; $3=$ misplaced N/A - not applicable 
with PPE use recommendations, and its dependence on the nature of the hazard and level of exposure. To the knowledge of the authors, this kind of study on nuclear industry workers and limited to specific PPE has not yet been conducted (7-13). This study shows a PPE usage profile that varies depending on the hazard, but also on the proposed PPE. The rate of positive answers concerning PPE availability was extremely high (100\%). According to the statement of the industrial hygienist and the independent expertise of PPE management and application, all of the provided PPE met the adequacy criteria regarding the tasks and hazards, and was regularly inspected.

\section{Limitations}

This study is limited by its objective and design. The global participation rate was $34 \%$. According to Morton et al. (14), even in well-designed case-control studies, response rates of approximately $50 \%$ are not uncommon. Sneyd and Cox (15) stated that a poor response rate can provide more opportunity for bias to occur but does not create a selection bias on its own, any more than a high response rate guarantees an unbiased estimate. A selection bias develops if the selection probabilities are different for cases and controls based on their exposure status (15). As in the exposure assessment study (4), the workers were selected randomly. Their participation corresponds to $10 \%$ of the EURODIF workforce for the period from 1978 to 2010, which is similar to our previous study $(3,5)$. Moreover, the analysis of the responses to exposure frequency and intensity showed reliable results, in agreement with other unbiased sources of exposure data such as industrial measurement data (4). We believe that a selection bias is not likely to be present in this study.

The representativeness of the answers can seem questionable considering the subjectivity related to risk. Having examined several of the uniform answers per workstation, we must admit that they can be a fairly

Table 3 Personal protection equipment use compliance across levels of exposure amount for the most prevalent exposure hazards: Homogeneity $\chi^{2}$ and linear trend test $\mathrm{p}$-values

\begin{tabular}{|c|c|c|c|c|c|c|c|c|c|c|c|c|}
\hline \multirow[t]{2}{*}{ Hazard type } & \multicolumn{2}{|c|}{$\begin{array}{l}\text { Breathing } \\
\text { protection }\end{array}$} & \multicolumn{2}{|c|}{ Work clothes } & \multicolumn{2}{|c|}{ Gloves } & \multicolumn{2}{|c|}{ Goggles } & \multicolumn{2}{|c|}{ Earmuffs } & \multicolumn{2}{|c|}{ Ear plugs } \\
\hline & $p$ hom & $p$ trend & $p$ hom & $p$ trend & $p$ hom & $p$ trend & $p$ hom & $p$ trend & $p$ hom & $p$ trend & $p$ hom & $p$ trend \\
\hline \multicolumn{13}{|l|}{ Radiological } \\
\hline $\begin{array}{l}\text { Enriched } \\
\text { uranium }\end{array}$ & 0.02 & $<0.01$ & 0.02 & $<0.01$ & 0.37 & 0.23 & $\mathrm{~N} / \mathrm{A}$ & $\mathrm{N} / \mathrm{A}$ & $\mathrm{N} / \mathrm{A}$ & $\mathrm{N} / \mathrm{A}$ & $\mathrm{N} / \mathrm{A}$ & N/A \\
\hline Natural uranium & 0.13 & 0.03 & 0.17 & 0.04 & 0.41 & 0.52 & $\mathrm{~N} / \mathrm{A}$ & N/A & N/A & N/A & N/A & N/A \\
\hline \multicolumn{13}{|l|}{ Chemical } \\
\hline TCE & $<0.01$ & 0.06 & $<0.01$ & $<0.01$ & 0.11 & 0.27 & 0.13 & 0.20 & N/A & $\mathrm{N} / \mathrm{A}$ & $\mathrm{N} / \mathrm{A}$ & N/A \\
\hline $\begin{array}{l}\text { Chlorinated } \\
\text { products }\end{array}$ & 0.06 & 0.33 & $<0.01$ & 0.02 & $<0.01$ & 0.73 & 0.10 & 0.20 & $\mathrm{~N} / \mathrm{A}$ & $\mathrm{N} / \mathrm{A}$ & $\mathrm{N} / \mathrm{A}$ & N/A \\
\hline $\begin{array}{l}\text { Fluorinated } \\
\text { products }\end{array}$ & 0.19 & 0.28 & 0.32 & 0.59 & 0.78 & 0.52 & 0.12 & 0.94 & $\mathrm{~N} / \mathrm{A}$ & $\mathrm{N} / \mathrm{A}$ & N/A & N/A \\
\hline $\begin{array}{l}\text { Aromatic } \\
\text { solvents }\end{array}$ & 0.09 & 0.49 & 0.09 & 0.38 & 0.37 & 0.20 & 0.17 & 0.61 & $\mathrm{~N} / \mathrm{A}$ & $\mathrm{N} / \mathrm{A}$ & N/A & N/A \\
\hline $\begin{array}{l}\text { Hydrocarbon } \\
\text { fuels }\end{array}$ & 0.07 & 0.56 & $<0.01$ & 0.62 & 0.02 & 0.78 & 0.14 & 0.89 & N/A & N/A & N/A & N/A \\
\hline Hydrazine & 0.91 & 0.20 & 0.54 & 0.71 & 0.97 & 0.34 & 0.70 & 0.09 & N/A & $\mathrm{N} / \mathrm{A}$ & N/A & N/A \\
\hline \multicolumn{13}{|l|}{ Physical \& fibres } \\
\hline Noise & $\mathrm{N} / \mathrm{A}$ & $\mathrm{N} / \mathrm{A}$ & $\mathrm{N} / \mathrm{A}$ & $\mathrm{N} / \mathrm{A}$ & $\mathrm{N} / \mathrm{A}$ & $\mathrm{N} / \mathrm{A}$ & $\mathrm{N} / \mathrm{A}$ & $\mathrm{N} / \mathrm{A}$ & $<0.01$ & $<0.01$ & $<0.01$ & $<0.01$ \\
\hline Heat & N/A & $\mathrm{N} / \mathrm{A}$ & 0.95 & 0.65 & $\mathrm{~N} / \mathrm{A}$ & $\mathrm{N} / \mathrm{A}$ & N/A & N/A & N/A & N/A & N/A & N/A \\
\hline \multicolumn{13}{|l|}{$\begin{array}{l}\text { Metal dusts/ } \\
\text { fibres }\end{array}$} \\
\hline Welding fumes & $<0.01$ & 0.03 & $<0.01$ & $<0.01$ & 0.21 & 0.02 & $\mathrm{~N} / \mathrm{A}$ & $\mathrm{N} / \mathrm{A}$ & $\mathrm{N} / \mathrm{A}$ & $\mathrm{N} / \mathrm{A}$ & $\mathrm{N} / \mathrm{A}$ & N/A \\
\hline Asbestos & 0.03 & 0.03 & $<0.01$ & 0.07 & $\mathrm{~N} / \mathrm{A}$ & N/A & N/A & $\mathrm{N} / \mathrm{A}$ & $\mathrm{N} / \mathrm{A}$ & $\mathrm{N} / \mathrm{A}$ & N/A & N/A \\
\hline Glass/rock wool & $<0.01$ & 0.09 & 0.07 & 0.10 & $\mathrm{~N} / \mathrm{A}$ & $\mathrm{N} / \mathrm{A}$ & $\mathrm{N} / \mathrm{A}$ & $\mathrm{N} / \mathrm{A}$ & $\mathrm{N} / \mathrm{A}$ & $\mathrm{N} / \mathrm{A}$ & $\mathrm{N} / \mathrm{A}$ & N/A \\
\hline
\end{tabular}

N/A: not applicable 
accurate reflection of the general behaviour of workers, but one which does not allow the characterisation of individual behaviour (16). Furthermore, this crosssectional study did not allow an analysis of the workers attitudes towards different pieces of PPE over time. The state of wear and the performance of the PPE could not be assessed experimentally in the frame of this study, but were assumed effective based on the tests and in-field studies performed by the company's hygienists and safety engineers. Despite these limitations, the observed results seem coherent and consistent with the previously collected data from the CEA/AREVA group.

\section{Attitude towards personal protective equipment}

We observed a lack of information on the exposure to metal dusts and fibres, which had the highest noanswer rate $(60 \%)$. The risk related to the presence of asbestos fibres is relatively recent; the first ever asbestos inventory made for the nuclear industry dates back to $1997(4,5)$, and this had perhaps caused a lack of awareness among the retired evaluators. The reasons for not using PPE seem to be in agreement with the data in the literature: earmuffs are reputedly less comfortable than earplugs $(9,17,18)$; heat protection overalls are known to be a hindrance (11, 19-21).

A more systematic use of PPE in highly exposed situations is particularly true for exposure to hazardous factors such as noise, TCE, uranium, and asbestos, and less evident for other chemical hazards. Heat is an exception to this observation, accounting for only $34 \%$ of the systematic use of anti-heat equipment, regardless of the amount of exposure. Uranium is the only hazard with a zero refusal of PPE usage, reflecting the workers' awareness about radiation-related risks specific to the nuclear industry, as well as about the potentially irreversible and dangerous health consequences. Heat and noise were the two main exposures due to the number of workstations involved and the amount of exposure. The attitude to heat appears significantly different from other hazards, with a low acceptance of wearing anti-heat coveralls for reasons of discomfort or hindrance. The discomfort of anti-heat clothes is largely discussed in the literature $(11,20-22)$ and was studied at EURODIF and other CEA/AREVA facilities. Finally, the preventive solution found for heat-related disorders was to reduce the exposure duration based on a model of heat stress and cardiac strain regulation (22-24) and provide rigorous medical monitoring, micro-breaks of 2 minutes, and intensive hydration.

The chemical risk was third in terms of protection, although the exposure to trichloroethylene and other halogenated solvents was higher than the exposure to certain uraniferous compounds. Furthermore, many of the chemicals used are classified as CMR (2), while uranium is not $(2,25,26)$. This confirms the difference in the perceptions and prioritizations of risks in the nuclear industry.

Among chemical hazard PPE, usage of anti-spray goggles was the least frequent. According to the results, misplacing the goggles was the main obstacle for their use. This was affirmed by the industrial hygienist at EURODIF and other AREVA companies, as well as by data from the literature $(7,27,28)$. The solution might be to provide the workers with a case, which would preclude this from occurring (7). Another case are workers wearing prescriptive glasses, who in a previous study neglected goggles due to a lesser risk perception (28).

Apart from the usefulness of these data for industrial safety and hygiene practices, we expect the results of this study to be of use in epidemiology and risk analysis. Using the data on individual and collective protection measurements and the attitude of EURODIF workers towards personal protective equipment, a model of individual exposure could be made, which would help estimate the internal radiation dose resulting from uranium exposure. The results of a previous work show that a combination of the JEM and internal dosimetry method allows for a more accurate estimation of the dose (6). The EURODIF JEM (4) was created as a basis for such an estimation, taking into consideration both radiation and nonradiation hazards.

\section{CONCLUSION}

The results from this study suggest that, in spite of the predominance of non-radiological physical and chemical exposure, EURODIF workers are more concerned about the radiation-related risks. This concern seems to be shared throughout the French nuclear industry. Regulations on chemical risk prevention are relatively recent, but their application should be supported by improvements to the PPE management system, effective communication from managers and supervisors, and encouraging the continuous use of PPE. 


\section{Acknowledgements}

The authors would like to thank Eric Knieczak, the EURODIF safety manager; Dr Michel Carles, occupational physician; Dr Alain Acker, AREVA Group coordinating physician; and all of the evaluators for their participation and support. The study was financed by the PIC Epidémiologie AREVA-IRSN 2008-2011.

\section{Conflict of interest}

The authors declare that they have no conflict of interest.

\section{REFERENCES}

1. Samson E, Guseva Canu I, Acker A, Laurier D, Tirmarche M, editors. Tracy U: The French cohort of uranium cycle workers [displayed 27 March 2013]. Available at http://www. irsn.fr/FR/Larecherche/publications-documentation/ Publications_documentation/BDD_publi/DRPH/Documents/ IRPA13-IRSN-poster-E-Samson-P01-67.pdf

2. Directive 2004/37/EC of the European Parliament and of the Council of 29 April 2004 on the protection of workers from the risks related to exposure to carcinogens or mutagens at work (Sixth individual Directive within the meaning of Article 16(1) of Council Directive 89/391/EEC) (codified version) [displayed 27 March 2013]. Available at http://eurlex.europa.eu/LexUriServ/LexUriServ.do?uri=OJ: L:2004:229:0023:0034:EN:PDF

3. Guseva Canu I, Molina G, Goldberg M, Collomb P, David JC, Perez P, Paquet F, Tirmarche M. [Development of a job exposure matrix for the epidemiological follow-up of workers in the French nuclear industry, in French]. Rev Epidemiol Sante Publique 2008;56:21-9. doi: 10.1016/j. respe.2007.11.001

4. Guseva Canu I, Faust S, Knieczak E, Carles M, Samson E, Laurier D. Estimating historic exposures at the European Gaseous Diffusion Establishment. Int J Hyg Environ Health 2012 [displayed 27 March 2013]. Available at http://dx.doi. org/10.1016/j.ijheh.2012.07.002

5. Guseva Canu I, Paquet F, Goldberg M, Auriol B, Bérard P, Collomb P, David JC, Molina G, Perez P, Tirmarche M. Comparative assessing for radiological, chemical, and physical exposures at the French uranium conversion plant: Is uranium the only stressor? Int J Hyg Environ Health 2009;212:398-413. doi: 10.1016/j.ijheh.2008.09.002

6. Guseva Canu I, Laurier D, Caër-Lorho S, Samson E, Timarche M, Auriol B, Bérard P, Collomb P, Quesne B, Blanchardon E. Characterisation of protracted low-level exposure to uranium in the workplace: A comparison of two approaches. Int J Hyg Environ Health 2010;213:270-7. doi: 10.1016/j.ijheh.2010.02.003

7. Lombardi DA, Verma SK, Brennan MJ, Perry MJ. Factors influencing worker use of personal protective eyewear. Accid Anal Prev 2009;41:755-62. doi: 10.1016/j.aap.2009.03.017
8. Hansia MR, Dickinson D. Hearing protection device usage at a South African gold mine. Occup Med 2010;60:72-4. doi: 10.1093/occmed/kqp114

9. Neitzel R, Seixas N. The effectiveness of hearing protection among construction workers. J Occup Environ Hyg 2005;2:227-38.

10. Packham C. Gloves as chemical protection - Can they really work? Ann Occup Hyg 2006;50:545-8. doi:10.1093/annhyg/ mel033

11. Pantalonia F, Capitaineb C, Le Duffc F, Stevea JM, Barberisa J. Tolérance physique au port de l'appareil respiratoire isolant chez les sapeurs-pompiers [Physical tolerance of fire fighters wearing self-contained breathing apparatus during training, in French]. Arch Mal Prof Environ 2010;71:790-7.

12. Salazar MK, Takaro TK, Connon C, Ertell K, Pappas G, Barnhart S. A description of factors affecting hazardous waste workers' use of respiratory protective equipment. Appl Occup Environ Hyg 1999;14:470-8.

13. Turner NL, Hodous TK. Respiratory protection in the mining industry. Occup Med 1993;8:143-54.

14. Morton LM, Cahill J, Hartge P. Reporting participation in epidemiologic studies: a survey of practice. Am J Epidemiol 2005;163:197-203. doi: 10.1093/aje/kwj036

15. Sneyd MJ, Cox B. Commentary: Decreasing response rates require investigators to quantify and report the impact of selection bias in case-control studies. Int J Epidemiol 2011;40:1355-7. doi: 10.1093/ije/dyr123

16. Persson R, Hansen ÅM, Garde AH, Kristiansen J, Nordander C, Balogh I, Ohlsson K, Ostergren PO, Ørbæk P. Can the job content questionnaire be used to assess structural and organizational properties of the work environment? Int Arch Occup Environ Health 2011;85:45-55. doi: 10.1007/s00420011-0647-2

17. Davis R. What do we know about hearing protector comfort? Noise Health. 2008;10:83-9.

18. Kahan E, Ross E. Knowledge and attitudes of a group of South African mine workers towards noise induced hearing loss and the use of hearing protective devices. S Afr J Commun Disord 1994;41:37-47.

19. Dolez PI, Vu-Khanh T. Recent developments and needs in materials used for personal protective equipment and their testing. Int J Occup Saf Ergon 2009;15:347-62.

20. Holmér I. Protective clothing in hot environments. Ind Health 2006;44:404-13

21. Ilmarinen R, Mäkinen H, Lindholm H, Punakallio A, Kervinen $H$. Thermal strain in fire fighters while wearing task-fitted versus EN 469:2005 protective clothing during a prolonged rescue drill. Int J Occup Saf Ergon 2008;14:718.

22. Malchaire J, Kampman B, Havenith G, Gebhardt HJ. Criteria for estimating acceptable exposure times in hot work environment, a review. Int Arch Occup Environ Health 2000;73:215-20.

23. Malchaire J, Piette A, Kampmann B, Mehnert P, Gebhardt H, Havenith G, Den Hartog E, Holmer I, Parsons K, Alfano G, Griefahn B. Development and validation of the predicted heat strain model. Ann Occup Hyg 2001;45:123-35.

24. Malchaire J, Kampmann B, Mehnert P, Gebhardt H, Piette A, Havenith G, Holmér I, Parsons K, Alfano G, Griefahn B. Assessment of the risk of heat disorders encountered during work in hot conditions. Int Arch Occup Environ Health 2002;75:153-62. 
25. International Agency for Research on Cancer (IARC). Ionizing Radiation, Part 2: Some Internally Deposited Radionuclides. IARC Monogr Eval Carcinog Risks Hum Vol 78. Lyon: IARC; 2001

26. United Nations Scientific Committee on the Effects of Atomic Radiation (UNSCEAR). Effects of ionizing radiation UNSCEAR 2006 Report to the General Assembly, New York (NY): United Nations; Volume I, 2008. 12p.

27. Mancini G, Baldasseroni A, Laffi G, Curti S, Mattioli S, Violante FS. Prevention of work related eye injuries: Long term assessment of the effectiveness of a multicomponent intervention among metal workers. Occup Environ Med 2005;62:830-5. doi: 10.1136/oem.2004.019570

28. Forrest KY, Cali JM, Cavill WJ. Use of protective eyewear in U.S. adults: results from 2002 national health survey. Ophtalmic Epidemiol 2008;15:37-41. doi: 10.1080/092865 80701609247 


\section{Sažetak \\ ODNOS PREMA OSOBNOJ ZAŠTITNOJ OPREMI U FRANCUSKOJ INDUSTRIJI NUKLEARNOGA GORIVA}

Ovo opisno presječno istraživanje ispituje usklađenost radnika s opremom u pogledu mnogobrojnih rizika u industriji nuklearnoga goriva. Inventar opreme izradio je stručnjak iz područja higijene rada, zadužen za zaštitnu opremu pri francuskoj tvornici za obogaćivanje urana EURODIF. Upitnik o svome odnosu prema zaštitnoj opremi ispunilo je 227 (10 \%) nasumično odabranih zaposlenih i umirovljenih radnika te tvornice. Podaci o izloženosti iz matrice profesionalne izloženosti u tvornici EURODIF upotrijebljeni su kako bi se utvrdilo ovisi li korištenje opreme o stupnju izloženosti. U istraživanju se izlaže model korištenja zaštitne opreme, koji ovisi o rizicima i dostupnoj opremi. Oprema za zaštitu od urana i rukavice među najbolje su ocijenjenima, a zaštitne naočale među najgorima. Ustanovili smo da, za većinu rizika za koje je poznato da mogu uzrokovati rak ili trajnu zdravstvenu štetu, povremena i sustavna uporaba opreme ovisi o stupnju izloženosti (test homogenosti, $p<0,05$; test trenda, $p<0,05$ ). Među radnicima je nužno poticati kontinuiranu uporabu opreme dugoročnim unaprjeđenjima sustava upravljanja i učinkovitom komunikacijom njihove uprave i nadzornika. Za kreiranje preciznog modela pojedinačne izloženosti nužno je razmotriti korištenje i učinkovitost osobne zaštitne opreme.

KLJUČNE RIJEČI: epidemiologija, radnici u nuklearnoj industriji, uran

\section{CORRESPONDING AUTHOR:}

Dr Irina Guseva Canu

Institut de Radioprotection et de Sûreté Nucléaire

Fontenay-Aux-Roses

Institut de Veille Sanitaire, Saint Maurice, France

E-mail: i.guseva-canu@invs.sante.fr 